\title{
STUDIES ON LEJEUNEACEAE SUBF. PTYCHANTHOIDEAE (HEPATICAE) II. TWO REMARKABLE SPECIES OF CAUDALEJEUNEA: C. GROLLEANA SPEC. NOV. AND C. CRISTILOBA (STEPH.) COMB. NOV.*
}

\section{S. R. GRADSTEIN}

Instituut voor Systematische Plantkunde, Utrecht

\section{SUMMARY}

Caudalejeunea grolleana Gradst. spec. nov. from Madagascar is referred to this genus with some doubt because of the absence of gemmiparous branches. Ptychocoleus cristilobus (Steph.) Steph. from S. E. Asia has gemmiparous branches and therefore is a true Caudalejeunea: C. cristiloba (Steph.) comb. nov. This species is remarkable by its complicated ciliate leaflobule and by its polystratose rhizoid-disc. Two subspecies are distinguished: ssp. cristiloba from Burma, Andaman Is., Thailand, and Singapore, and ssp. samoana (Steph.) comb. nov. (Caudalejeunea samoana Steph.) from Samoa.

Both $C$. grolleana and $C$. cristiloba have a 4-5-carinate perianth, which shows that the trigonous perianth present in most species of Caudalejeunea is not a stable character of this genus.

\section{INTRODUCTION}

The tropical liverwort-genus Caudalejeunea Steph. at the moment comprises about 13 species: C. lehmanniana (Gott.) Evans (the type species) from America, C. africana (Steph.) Steph., C. dusenii Steph., C. hanningtonii (Mitt.) Schiffn., C. katangensis VandenB., C. lewallei VandenB., C. madagassa Steph. (?), C. tricarinata Jones, and $C$. yangambiensis (VandenB.) Jones from Africa, $C$. circinata Steph., $C$. reniloba (Gott.) Steph., C. samoana Steph. (see below), and C. stephanii Spruce ex Steph. from Asia and the Pacific. Most of the species seem to have 1) a flattened and rather pale appearance, 2) prostrate stems and prostrate or erect branches which in the latter case may produce disciform gemmae, 3) a hyalodermis, 4) retuse underleaves, 5) cells with one to three intermediate thickenings on the longer walls and subcordate trigones (trigone with two convex sides, one \pm straight side), 6) homogeneous oilbodies, 7) no innovations, 8) female bracts with reduced lobule, 9) a flattened, trigonous, more or less winged perianth. According to JONES (1953) the species preferably grow on twigs and small branches of shrubs or on lianes rather than on the stems of trees; they can also be epiphyllous. The genus in its present circumscription has affinity both to Lopholejeunea and to Schiffneriolejeunea (=Ptychocoleus p.p.).

In the course of my work on Acrolejeunea and Schiffneriolejeunea (GRADSTEIN 1974) I came across two interesting species evidently belonging to Caudalejeunea.

* Mededelingen van het Botanisch Museum en Herbarium van de Rijksuniversiteit te Utrecht No. 406. 
Both species differ considerably from the type species of the genus, $C$. lehmanniana (Gott.) Evans (cf. Evans 1907, p. 553-557, Pl. 33), and therefore I studied them in some detail. One of them, Caudalejeunea grolleana nov. spec. from Madagascar, is assigned here to Caudalejeunea with some misgivings. The other species, known as Ptychocoleus cristilobus (Steph.) Steph. from S.E. Asia, is a true Caudalejeunea because of the presence of gemmiparous shoots. The latter species actually appeared to be closely related to the poorly known Caudalejeunea samoana Steph. which is reduced here to subspecific rank.

Both $C$. grolleana and $C$. cristiloba are remarkable by their 4-5-carinate perianth. This shows that the trigonous perianth present in most species of Caudalejeunea is not a stable character of this genus.

\section{Caudalejeunea grolleana Gradst. spec. nov. $(P l . ~ I)^{*}$}

Planta minor, olivacea, monoica. Folia subimbricata, erecto-patentia, oblonga apice rotundata, integerrima, lobulis parvis, 1-2-dentatis; cellulae medianae 16-32 $\times 18-22 \mu \mathrm{m}$, parietibus tenuibus, trigonis conspicuis subcordatis. Amphigastria obtrapezoidea, caule triplo latiora, apice leviter retusa. Gynoecium innovatione nulla; bracteae inequaliter bilobae, lobo oblique patulo, oblongo, apice rotundato, integerrimo, lobulo multo minore erecto, lanceolato; bracteola ovata, margine leviter undulata, apice breviter et anguste incisa, lobis obtusis conniventibus; perianthium immersum, 4-5-plicatum, plicis irregulariter subalatis.

Plants autoicous, small, rarely longer than $5 \mathrm{~mm}, 1-1.3 \mathrm{~mm}$ wide, dull olivegreen or brownish when dry, irregularly pinnate, growing appressed in rather dense mats on bark of trees. Branches short or long, never microphyllous, generally of the Lejeunea-type originating at right angles with the axis and not curving away from the substrate; sterile Frullania-type branches rarely present. Stem $80-120 \mu \mathrm{m}$ in diam.; ventral merophyte 4 cells wide, the ventral cortical cells in optical view 15-25 × 30-50 $\mu \mathrm{m}$, cell-walls slightly thickened, dorsal cortical cells arranged in straight rows, slightly thick-walled, subrectangular, 15-22 $\times 30-40 \mu \mathrm{m}$; stem in transverse section with 11-13 yellowish-brown cortical cells surrounding 12-17 smaller, thicker-walled yellowish medullar cells; dorsal cortical cells slightly larger than ventral cortical cells: dorsal cells 21-24 $\mu \mathrm{m}$ high, ventral cells 16-20 $\mu \mathrm{m}$ high; medullar cells $10-13 \mu \mathrm{m}$ in diam., in longitudinal section very long and tapering to narrow ends.

Leaves subimbricate, flattened, when dry hardly modified, erecto-patent and sometimes falcate, near the stem-apex suberect. Leaf-insertion narrowly Sshaped, the dorsal insertion line covering only half the length of the merophyte. Lobe ovate-oblong, $0.6-0.8 \times 0.45-0.6 \mathrm{~mm}$, sometimes smaller and deformed, the dorsal base nearly straight, not extending beyond the stem, the dorsal margin gradually curved towards the rounded apex, the ventral margin flat,

*) I dedicate this new species to Dr. R. Grolle (Jena) to whom I am much indebted for providing the material and for useful remarks on the taxonomic position of the species. 


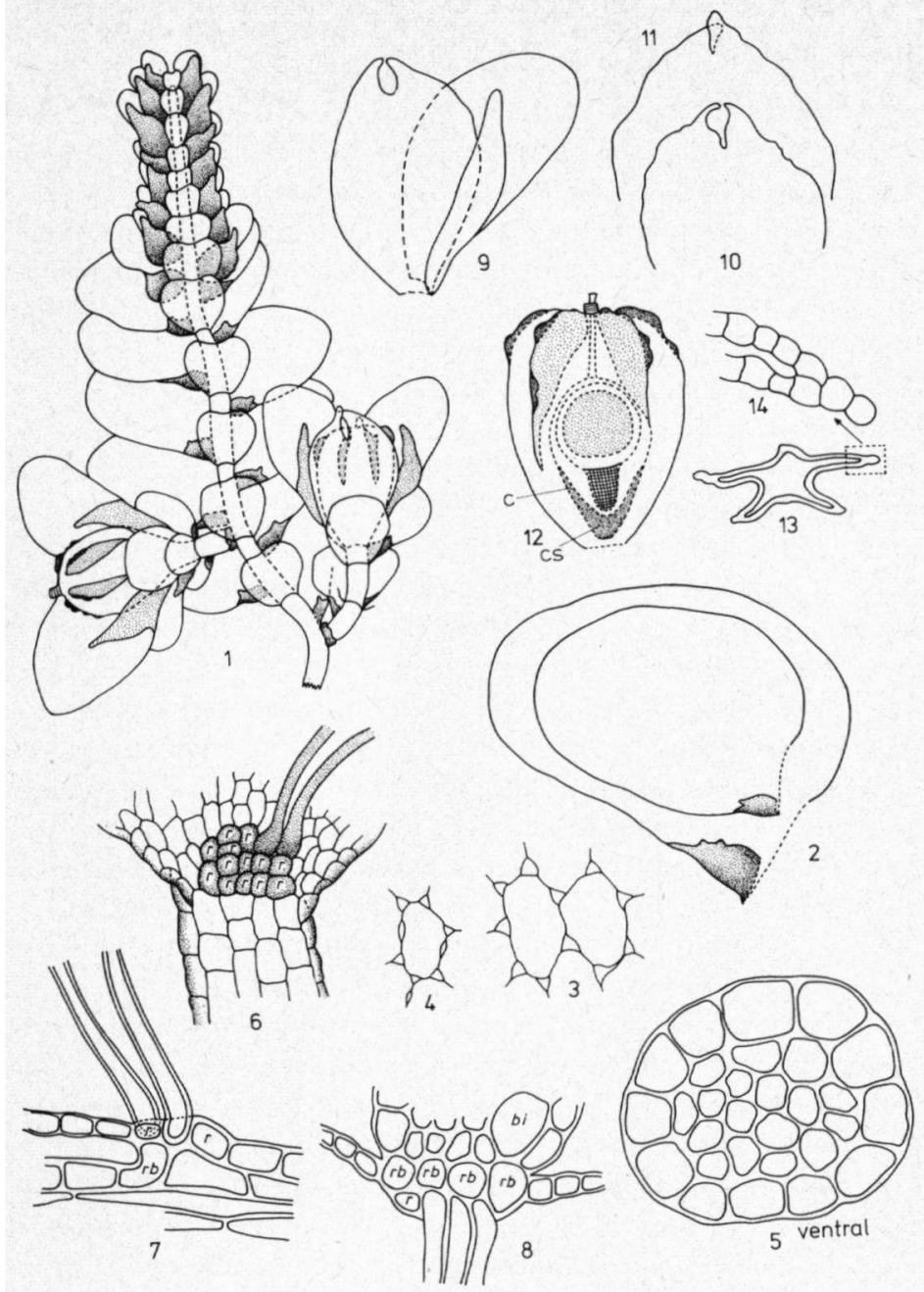

P1. I Caudalejeunea grolleana Gradst.

Figs. 1-5, leafy stem: 1.- habitus with two gynoecia (inner bracteole removed in left gynoecium) and male spike $(27 \times)$; 2.- leaves $(60 \times)$; 3.- cells from centre of leaf $(400 \times)$; 4.- cell from centre of underleaf $(400 \times) ; 5$.- stem in transverse section $(400 \times)$.

Figs. 6-8, base of underleaf with rhizoid disc: 6.- optical view $(180 \times)$; 7.- longitudinal section $(260 \times) ; 8 .-$ transverse section $(260 \times) ; r=$ rhizoid initial cell, $\mathrm{rb}=$ rhizoid-disc initial cell, bi $=$ Lejeunea-type branch initial cell.

Figs. 9-14, gynoecium: 9.- inner bract and bracteole in young gynoecium $(60 \times)$; 10.- inner bracteole, almost mature $(60 \times)$; 11.- inner bracteole, mature $(60 \times)$; 12.- perianth $(55 \times)$, $c=$ calyptra, cs = calyptral stalk; 13.- perianth above, in transverse section $(65 \times)$; 14.perianth wing in tranverse section $(280 \times)$.

All figures drawn from the type. 
forming a nearly straight line with the keel, the keel weekly curved, at an angle of $70^{\circ}-90^{\circ}$ with the axis, slightly decurrent. Cells arranged in slightly diverging rows, hexagonal, 26-32 $\times 18-22 \mu \mathrm{m}$ in the upper half of the lobe, towards the base up to $40 \mu \mathrm{m}$ long, at the margins small and subquadrate, 9-13 $\mu \mathrm{m}$ high; trigones small to moderate in size, with two convex sides and one straight or slightly concave side, sometimes with three convex sides; intermediate cell-wall thickenings rare in the middle of the lobe, becoming more frequent towards the base and the margins. Lobule small, ovate-triangular with an oblique apex, inflated, up to $0.2 \times 0.15 \mathrm{~mm}$, the free margin incurved, with $1-2(-3)$ rudimentary teeth of $1(-2)$ cells; hyaline papilla (vanishing) at the base of the first tooth on the inner side of the lobule.

Underleaves contiguous, small, obtrapezioid, 0.18-0.3 mm long and 0.25$0.35 \mathrm{~mm}$ wide, three times wider than the stem, appressed to the stem and slightly gibbose, the apex truncate to retuse, the margins flat, the line of insertion straight, not or hardly decurrent; cells subquadrate, 16-20 $\times 19-25 \mu \mathrm{m}$, becoming longer towards the base, the trigones small with subequal sides, the intermediate thickenings more frequent than in the leaves, one to two per cell.

Rhizoids in short brownish fascicles originating from an inconspicuous rhizoid-disc of relatively small cells at the base of the underleaf; rhizoid-disc on transverse section unistratose, with four (cortical) rhizoid-disc initial cells.

Androecia in slender spikes terminating a stem or branch, more rarely intercalary; spikes of 4-8 series of bracts and bracteoles, the bracts suberect, much smaller than the leaves and closely imbricate, strongly saccate with the keel arched, subequally bifid, the lobe $0.25-0.3 \times 0.2 \mathrm{~mm}$, the lobule hypostatic (free margin ventrally overlapping the lobule of the younger bract); bracteoles present throughout the spike, smaller and narrower than the underleaves, virtually without rhizoids; antheridia not seen. Gynoecium on a short lateral branch without innovations, bearing 2-3 series of leaves and underleaves and only $1(-2)$ series of (larger) bracts and bracteoles; inner bract unequally bifid to $3 / 5$ of its length with a sharp and straight keel, the lobe obliquely spreading and flat, narrowly obovate-oblong, up to $1 \times 0.5 \mathrm{~mm}$, with broadly rounded apex, the lobule much smaller, lanceolate beyond the keel with obtuse apex, up to $0.6 \times 0.2 \mathrm{~mm}$, the margins flat with a distinct row of quadrate cells; bracteole erect and appressed to the perianth, ovate, up to $0.75 \times 0.5 \mathrm{~mm}$, the margins undulate-subentire, the apex shallowly and narrowly bifid with obtuse and more or less connivent lobes.

Perianth slightly immersed, obovate, $0.6 \times 0.4 \mathrm{~mm}$, weakly inflated ventrally, with 4-5 sharp keels: two lateral keels extending over the whole lenght of the perianth, two ventral keels (inserted on the sides of a wide rounded ventral keel) extending halfway down, and sometimes one small dorsal keel; lateral and ventral keels on the back with rudimentary wing-like appendages; beak very short, 1-2 cells long; upper cells ca. $20 \mu \mathrm{m}$, with rather large bulging trigones, towards the base elongated with much thinner walls. Calyptra 1-2-stratose around the capsule of the immature sporophyte, becoming thicker around the developing seta and foot, the outer calyptral cells thinwalled, subquadrate, 2-3 times larger 
than the inner cells, the calyptral stalk very short.

Sporophyte (immature): with a foot of a few large, bulging cells, an articulate seta of about 10 cells high, in transverse section with 16 outer and 4 inner cells (?) and a globose capsule, 2-stratose, at base with 3-4 layers of thin-walled cells.

Distribution: Madagascar.

Specimens seen: Nossi-Bé, Lokobe natural reservation, on bark in primary forest, alt. ca. $100 \mathrm{~m}$, leg. M. Onraedt nr. M. 5119, 15. VII. 1971 (HOLOTYPE hb. Onraedt (Walonne), isotypes in hb. Grolle (Jena), U). Antsohy forest, east of Anivorano-Nord, on dead wood in forest, leg. G. Cremers $n r$. 2524a, 18. VIII. 1973 (hb. Onraedt (Walonne), hb. Grolle (Jena).

Caudalejeunea grolleana is an elegant and tiny species which is recognised by its widely spreading, oblong leaves and female bracts with entire margins and a rounded apex, by its obtrapezoid underleaves and by its perianth which has four sharp keels with rudimentary wing-like appendages. The type material contains pale olive-green plants with reduced leaf-lobules which indicates that the plants came from a relatively humid habitat. The other collection available contains brownish plants with better developed lobules (very much like those in certain species of Lopholejeunea!) and both Lejeunea-type and Frullania-type branches. These plants also have more conspicuous cell-wall thickenings, female bracts with slightly shorter and wider lobules and female bracteoles with hardly connivent lobes.

The position of this species in Caudalejeunea is questionable because of the absence in our material of gemmiparous branches. C. grolleana also deviates from typical species of Caudalejeunea in the relative rarity of intermediate thickenings in the cell-walls and in the perianth having 4-5 instead of three keels. Thes ame deviations are, however, found in the otherwise very different southeast Asian Caudalejeunea cristiloba (Steph.) Gradst. (see below). In both species the perianth has two sharp ventral keels which arise as accessory plicae on the lateral sides of a wide and rounded ventral keel.

Perianths with more than one ventral keel are also reported in Caudalejeunea yangambiensis (VandenB.) Jones (cf. Jones 1957) and in C. katangensis VANDENBERGEN (1972).

In habit Caudalejeunea grolleana resembles Ptychocoleus occultus (Steph.) Steph. (= Schiffneriolejeunea occulta (Steph.) Gradst.) from tropical West Africa. The latter species differs mainly in 1) the stem with the ventral cortical cells brownish pigmented and much smaller in size than the dorsal cortical cells, 2) the larger leaf-lobule which has only one tooth, 3) the transversely ovate underleaves, 4) the cordate, Brachiolejeunea-type trigones, 5) the subequally bifid female bracts. The stem anatomy and the female bracts serve to distinguish between Caudalejeunea and Schiffneriolejeunea. Both genera also have different oilbodies (homogeneous in Caudalejeunea and segmented in Schiffneriolejeunea) but unfortunately in the collections available of $C$. grolleana the oilbodies were degenerated. 

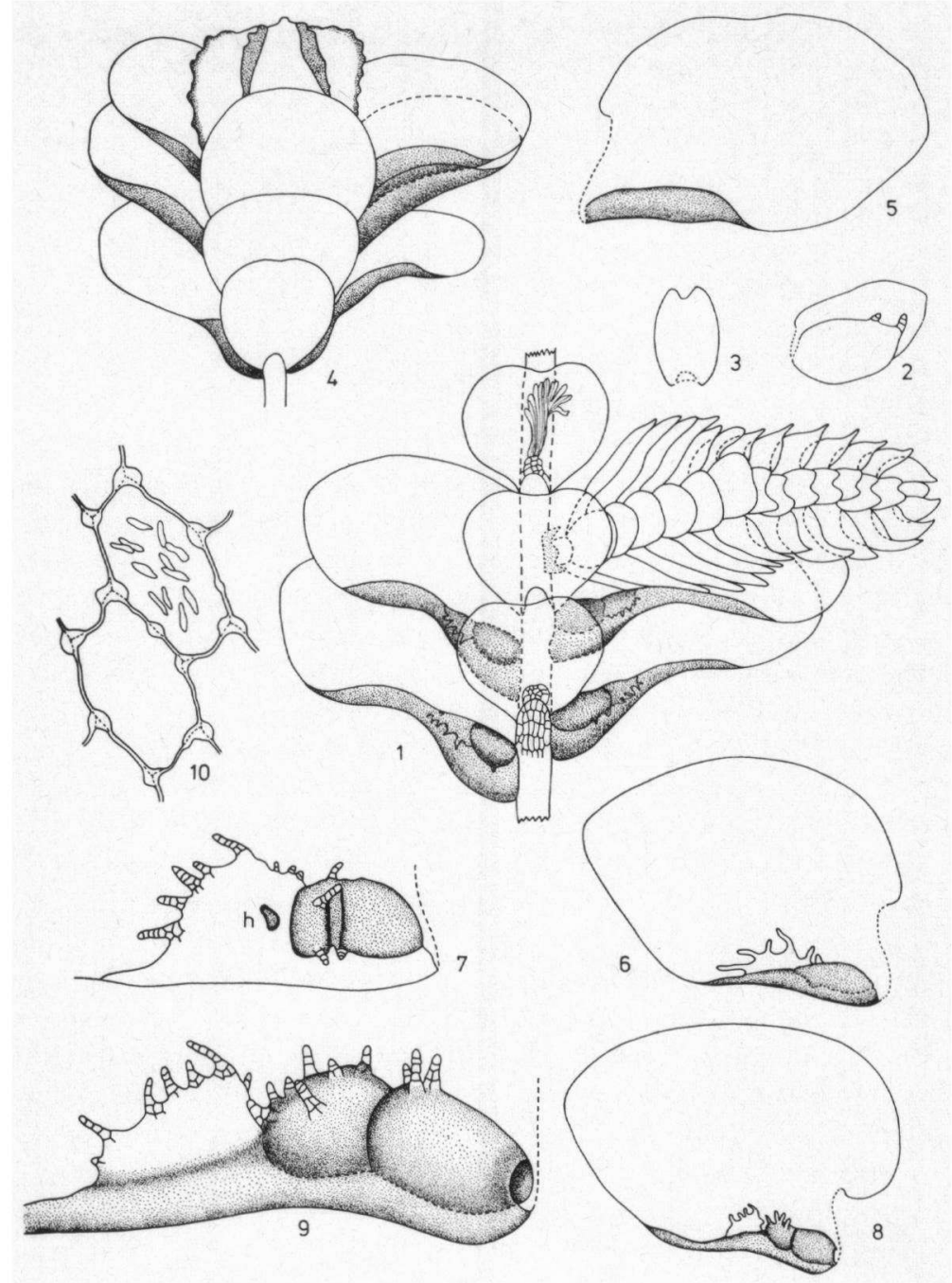

PI. II Caudalejeunea cristiloba (Steph.) Gradst.

Figs. 1-7, ssp. cristiloba: 1.- stem with male spike $(30 \times)$; 2.- male bract $(50 \times)$; 3.- male bracteole $(50 \times)$; 4.- gynoecium $(20 \times)$; 5.- female bract $(30 \times)$; 6.- stem-leaf, spread out $(30 \times)$; 7.- dissected lobule, seen from the inner side, from a branch-leaf $(65 \times), h=$ hyaline papilla.

Figs. 8-10, ssp. samoana (Steph.) Gradst.: 8.- stem-leaf, spread out $(20 \times)$; 9.- dissected lobule, seen from the inner side, from a stem leaf $(65 \times)$; 10 . leaf-cells, showing wall-thickenings and oilbodies $( \pm 600 \times)$.

Figs. 1-7 drawn from the type. Figs. 8-10 drawn from Schultze-Motel 3778. 

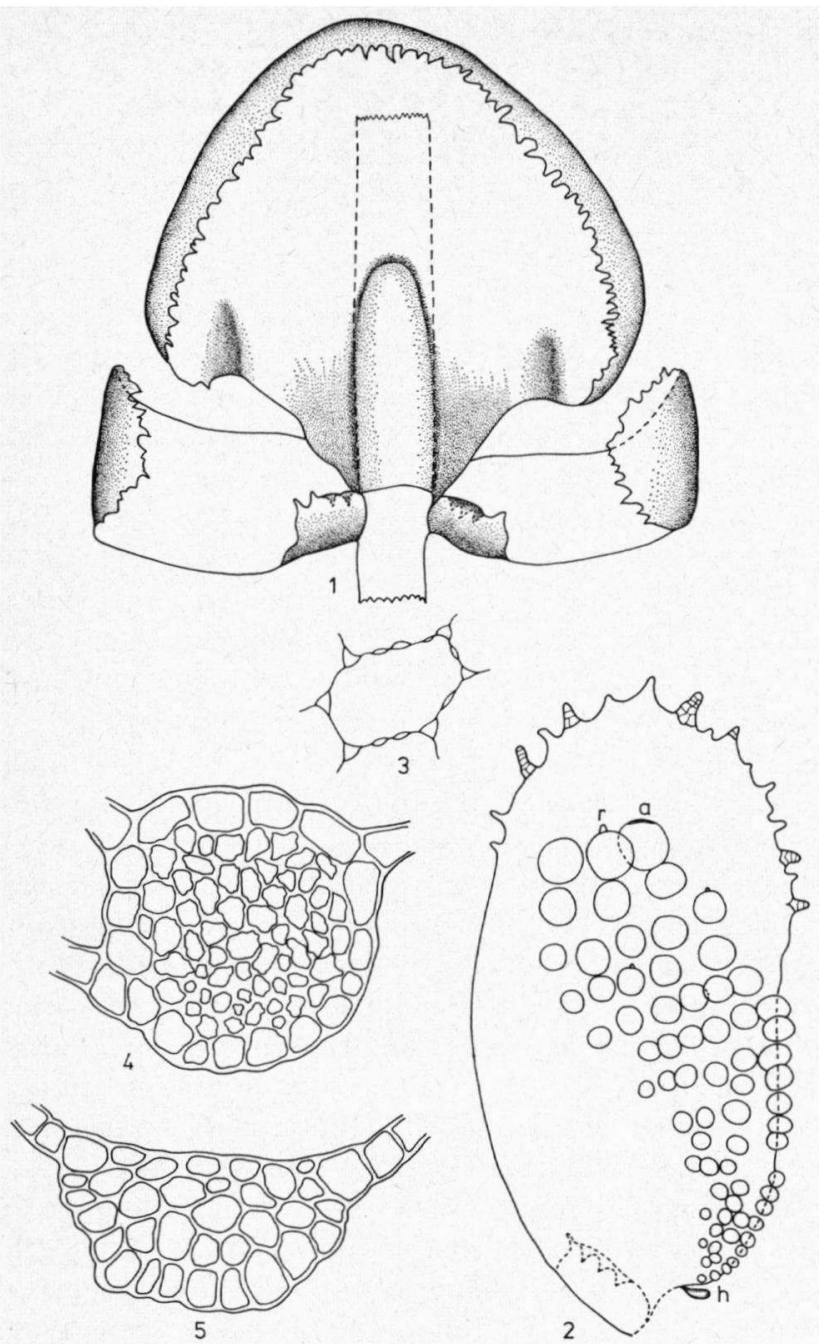

PI. III Caudalejeunea cristiloba (Steph.) Gradst.

Figs. 1-3, gemmiparous shoot: 1.- ventral view, showing the enormous underleaf $(30 \times)$; 2.- apical leaf, showing the characteristic arrangement of the gemmae in rows along the dorsal leaf-margin (cf. DeGENKolbe 1937, fig. 95), a = place of attachement to the leaf-cell, $\mathbf{r}=$ rhizoid developing at place of attachement in \pm mature gemmae, $\mathbf{h}=$ hyaline papilla, $(65 \times)$; 3.- leaf-cell with Caudalejeuneoid wall-thickenings $(400 \times)$.

Figs. 4-5, stem-anatomy: 4.- stem of fertile plant in transverse section $(180 \times)$; 5.- rhizoiddisc in transverse section $(280 \times)$.

Figs. 1-3, 5 drawn from ssp. samoana, Schultze-Motel 3778.

Fig. 4 drawn from the type of ssp. cristiloba. 
2. Caudalejeunea cristiloba (Steph.) Gradst. comb. nov. (Pls. II, III)

Acrolejeunea cristiloba Steph., Hedwigia 34: 56 (1895)

Ptychocoleus cristilobus (Steph.) Steph., Spec. Hep. V: 41 (1912); Verdoorn, Ann. Bryol. Suppl. Vol. 4: 130 (1934); Bischler, Revue Bryol. \& Lichenol. 33: 431, 433, fig. 61 (1965).

Plants autoicous, rather large, up to $3 \mathrm{~cm}$ long, 2-2.5 $\mathrm{mm}$ wide, yellowish-green becoming dull-brown when dry, irregularly pinnate, creeping on wood with prostrate stems and branches and occasionally (especially in ssp. samoana) with turgid, erect gemmiparous shoots which are strongly inrolled when dry. Branches of the Lejeunea-type originating at the ventro-basal side of a leaf, with a conspicuous 3-lobed collar.

Stem 170-200 (-250) $\mu \mathrm{m}$ in diam., with thick-walled cells; ventral merophyte 4-10 cells wide, the ventral cortical cells in optical view rectangular, $18-30 \times$ $60-90 \mu \mathrm{m}$; dorsal cortical cells arranged in straight rows, quadrate, $35-45 \mu \mathrm{m}$, much wider and shorter than the ventral cortical cells; stem in transverse section with $17-20(-28)$ yellowish-brown cortical cells surrounding $55-65(-80)$ smaller, yellowish medullar cells; dorsal cortical cells $26-30 \mu \mathrm{m}$ high, ventral cortical cells 20-25 $\mu \mathrm{m}$ high; medullar cells $15-25 \mu \mathrm{m}$ in diam., in the ventral merophyte with relatively narrower lumina and thicker walls.

Leaves imbricate, clasping the stem when dry, spreading when wet and tending to become falcate, dorsally curving upwards and becoming strongly convex; dorsal leaf-insertion line rather oblique, covering the whole lenght of the merophyte. Lobe ovate-oblong, $1.2-1.5 \times 0.8-1.1 \mathrm{~mm}$, the dorsal base semicordate to subauriculate, slightly extending beyond the stem, the dorsal margin tapering towards a rounded or obtuse, flat apex, the ventral margin strongly incurved, when spread out forming an angle of $150^{\circ}$ with the keel, the keel strongly curved at base, making an angle of $45^{\circ}$ with the axis, not decurrent. Cells arranged in straight rows, elongate-hexagonal, $35-45(-50) \times 20-25 \mu \mathrm{m}$ in the upper half of the lobe, wider at the base, at the margins subquadrate, 14-18 $\mu \mathrm{m}$ high; cells with conspicuous cordate trigones and with rounded intermediate thickenings, one or two per cell and only one on each cell-wall. Lobule involute and \pm invisible in optical view, when spread out rectangular, $0.55-0.6(-0.8) \times 0.2-0.25$ $(-0.4) \mathrm{mm}$, strongly inrolled and saccate over half of its lenght, flattened in the upper part; saccate part distally with a few short ciliate teeth on the inner surface and on the free margin, the sac sometime transversally constricted and tending to become divided into two sacs (in larger, sterile plants!); flattened part with five to ten long ciliate teeth along the free margin, the teeth straight or curved, up to twelve cells long and up to five cells wide at base, often a few short teeth present at the transition towards the sac; hyaline papilla on the inner side of the lobule in the centre of the flattened part. Oilbodies numerous, in all cells, 10-15(-25) per cell, linear-oblong, $4-8 \times 1.5-2.5 \mu \mathrm{m}$, homogeneous (?, only seen in dried material).

Underleaves large, transversely obovate, $0.8-1.2 \times 0.6-0.9 \mu \mathrm{m}$, gibbose, 
cuneate to slightly decurrent at base, the apex truncate to retuse, the margins flat or slightly incurved, the line of insertion deeply arched; cells 24-30 $\times$ $15-20 \mu \mathrm{m}$, the wall-thickenings as in the leaves.

Rhizoids in short fascicles originating from a rigid, dark brown rhizoid-disc; rhizoid-disc on transverse section polystratose (!), with four rhizoid-disc initial cells.

Androecia in short spikes terminating a stem or a leafy branch; bracts and bracteoles in up to 8 series, the bracts much smaller than the leaves and closely imbricate, strongly saccate, unequally bifid, the lobe ovate-triangular, $0.35-0.25$ $\mathrm{mm}$, the lobule $2 / 3$ the lenght of the lobe, hypostatic, at apex with a tooth of 2-3 cells; bracteoles present throughout the spike, longer than wide, $0.25 \times$ $0.20 \mathrm{~mm}$, shallowly bifid. Bracts diandrous. Gynoecium on a short lateral branch with bracts and bracteoles in two series, becoming slightly larger than the leaves and underleaves, the inner series squarrose and forming a "flowerlike" involucre around the perianth; lobe of the inner bract obovate-oblong, $1.8 \times 1.1 \mathrm{~mm}$, with entire or obscurely toothed margins tapering to a rounded apex, the lobule reduced to a narrow incurved fold, much shorter than the lobe, without teeth; inner bracteole $2 / 3$ the lenght of the lobe, suborbicular, the apex rounded or retuse, the margins narrowly recurved and sometimes with a few blunt teeth near the apex; a small "paramphigastrium" sometimes present just below the apex of the bracteole.

Perianth not or slightly emergent, rather flattened, obpyriform-obcordate, basically with three wide, rounded keels (two lateral, one ventral), becoming sharply 4(-5)-carinate above with two lateral keels, two ventral keels and sometimes one small dorsal keel; lateral and ventral keels near the apex with rudimentary wing-like appendages; beak four cells long.

Sporophyte not seen.

Vegetative propagation by means of disciform, multicellular gemmae arising from cells along the acroscopic margin on the adaxial surface of the squarrose apical leaves ( $P l . I I I 2)$ on specialised gemmiparous shoots; gemmiparous shoots lateral or terminating the stem, erect, turgid, strongly inrolled when dry, with very closely inserted leaves and underleaves; axis $0.3 \mathrm{~mm}$ in diam, cortical cells in optical view 45-120 $\times 45-60 \mu \mathrm{m}$, in transverse section larger than the medullar cells. Leaves erecto-patent, the lobe ligulate, the apex rounded and widely incurved, the margins dentate near the apex, the cells typically Caudalejeuneoid with subcordate trigones and one to three intermediate thickenings on the longer cell-walls; lobule rather poorly developed, not conspicuously saccate, the free margin incurved with a few ciliate teeth; underleaves very large, almost entirely covering the leaves, suborbicular-obcuneate, with rounded apex, gibbose, the margins revolute and dentate, decurrent. Rhizoids absent, rhizoid disc reduced, unistratose.

Distribution: Burma, Andaman Islands, Thailand, Singapore, Samoa.

Ecology: On stems and twigs of trees and shrubs in rather open, dry bushes in coastal areas. 
Caudalejeunea cristiloba is easily recognised by the structure of the leaf lobule which is unique in the Ptychanthoideae. Also remarkable are the polystratose rhizoid-discs (Pl. III, fig. 6). Gemmiparous shoots are absent in the type material but $I$ found them in a fragmentary collection from Singapore (leg. Verdoorn) in which they occur together with a few gynoecia on the same plant. The gemmiparous shoots resemble those of Caudalejeunea circinata, $C$. dusenii, and C. yangambiensis. The latter species also shares with $C$. cristiloba the presence of a "paramphigastrium" (significance still unknown!) Gemmiparous shoots are copiously present in the collections from Samoa which STEPHANI (1908) described as Caudalejeunea samoana. A beautiful specimen of this species was recently collected by Schultze-Motel (nr. 3776) from which material the description of the oilbodies was taken. It should be noted that Stephani in his original description of $C$. samoana mistook the gemmiparous shoots for female branches.

The morphological differences between $C$. cristiloba and $C$. samoana are only minor ones. Most striking are the differences in size and the presence of two (in stead of one) closed sacs in the lobule of $C$. samoana. In sterile plants of C. cristiloba, however, there is a tendency for the plants to become larger and the sac of the lobules to divide transversally (cf. Man G 15551, and Kitagawa $T$ 11866). It can easily be visualised that this tendency has become strongly expressed in the geographically isolated Samoan population. Until further collections come to light it seems most appropriate to retain $C$. samoana as a subspecies of $C$. cristiloba. The two taxa are separated by the following key:

Plants 2-2.5 mm wide, leaves up to $1.5 \times 1 \mathrm{~mm}$. Lobule with 1 closed sac. Burma, Andaman Is., Thailand, Singapore.............. ssp. cristiloba;

Plants 3-3.5 mm wide, leaves $2-2.5 \times 1.5 \mathrm{~mm}$. Lobule with 2 closed sacs. Samoa ......................................ssp. samoana.

a. C. cristiloba ssp. cristiloba

Specimens seen: Burma: sine loc., Micholitz s.n. (BM). Andaman Is.: Port Blair, in the jungle, E. H. Man s.n. 1890 (HOLOTYPE in G (nr. 011023), ISOtypes in G (nr. 15551, 15548), PARAtypes in G (nr. 01 1024), BM).

Thailand: Phagnga, Thap Put, on tree trunk, alt. $80 \mathrm{~m}$, N. Kitagawa T 11866 (G); Plain of Makam, near Chantburi, on twigs in dry dipterocarp forest, alt. 50-100 m, Th. Sorensen et al. 6764, 13.I.1958 (NICH). SINGAPORE: on tree trunks in botanical garden, ca. $20 \mathrm{~m}$, Fr. Verdoorn s.n., IV. 1930 (F).

The authentic material of Caudalejeunea cristiloba came from Herbarium Levier and was distributed among several herbaria (sub nom. Acrolejeunea cristiloba). Apparently the material was a mixture of $C$. cristiloba and the habitually very similar Ptychocoleus hasskarlianus (Gott.) Steph. because in several packets I only found the latter species (cf. G 15549, G 15552, G 15550, BM, H). 
b. C. cristiloba ssp. samoana (Steph.) Gradst. comb. nov.

Caudalejeunea samoana Steph. in Rechinger, Denkschr. Akad. Wiss. Wien 81: 296 (1908); idem, Spec. Hep. V: 16 (1912); Verdoorn, Blumea 1: 223 (1934).

Larger than ssp. cristiloba, stem with leaves 3-3.5 mm wide, the leaves 2-2.5 $\times$ $1.5 \mathrm{~mm}$, the dorsal leaf base auriculate, the lobule always with two closed sacs, the distal sac smaller and covered with cilia, the lobule at apex very gradually continuing into the ventral leaf-margin. Gametoecia not seen. With numerous gemmiparous shoots.

Specimens seen: SAMOA: Isl. Upolu, Mulinuu, in mangrove bush on branches of Clerodendron inerme, Rechinger 2728 ("998" in sched.) (HOLOTYPE in G nr. 16355); idem, Mulivai, beach, on stems of Cocos, W. Schultze-Motel 3776, 7.V.1971 (B, JE, U).

\section{ACKNOWLEDGEMENTS}

I thank Dr. K. U. Kramer for correcting the manuscript and Mr. T. Schipper for inking the drawings. For the loan of herbarium specimens I express my gratitude to: Dr. C. E. B. Bonner (Conservatoire Botanique, Geneva), Mr. A. Eddy (British Museum), Dr. R. Grolle (Jena), Dr. S. Hattori \& Dr. M. Mizutani (The Hattori Botanical Laboratory), Dr. R. Rollins (Farlow Herbarium), and Dr. O. Vitikainen (Botanical Museum, Helsinki).

\section{REFERENCES}

DegenKolbe, W. (1937): Brutorgane bei beblätterten Lebermoosen. Ann. Bryol. 10: 43-96, 112 figs.

Evans, A. W. (1907): Hepaticae of Puerto Rico VIII. Symbiezidium, Marchesinia, Mastigolejeunea, Caudalejeunea, and Bryopteris. Bull. Torrey Bot. Club 34: 533-568, pls. 31-33.

GradsteIn, S. R. (1974): Studies on Lejeuneaceae subf. Ptychanthoideae I. Nomenclature and taxonomy of Ptychocoleus, Acrolejeunea and Schiffneriolejeunea. J. Hattori Bot. Lab. 38: in the press.

Jones, E. W. (1953): African Hepatics. IV. The genus Caudalejeunea. Trans. Brit. Bryol. Soc. 2(2): 164-171, 2 figs.

- (1957): African Hepatics XII. Some new or little known Lejeuneaceae. Trans. Brit. Bryol. Soc. 3 (2): 191-207.

StePhan, F. (1908): Hepaticae. In K. Rechinger, Botanische und zoologische Ergebnisse einer wissenschaftlichen Forschungsreise nach den Samoainseln, dem Neuguinea-Archipel und den Salomonsinseln. Denkschr. Math.-Nat. Klasse Akad. Wiss. Wien 85: 197-201.

VandenBerghen, C. (1972): Hépatiques et Anthocerotées. In: J. J. Symoens (Ed.), Exploration hydrobiologique du bassin du Lac Bangweolo et du Luapula, VIII (1): 1-202, 86 figs. 